\title{
Synthesis and Antibacterial Activity of 2-(Substituted phenyl)-5-(pyridin-4-yl)-1,3,4-oxadiazoles
}

\author{
I. $\mathrm{SINGH}^{1^{*}}$ and A. KUMAR ${ }^{2}$ \\ ${ }^{1}$ Department of Chemistry, J.V College Baraut (Baghpat) U.P., 250611, India \\ ${ }^{2}$ Department of Community Medicine, LLRM Medical College, Meerut U.P., 250004, India \\ drarunmrt@gmail.com
}

Received 31 August 2014 / Accepted 25 September 2014

\begin{abstract}
Ethyl pyridine-4-carboxylate (1) treated with hydrazine hydrate in methanol give pyridine-4-carboxy hydrazide (2). Compound 2 react with substituted aroyl chlorides affords $N$-substituted aroyl pyridine-4-carbonyl hydrazines (3-9), which on treatment with $\mathrm{POCl}_{3}$ yield 2(substituted phenyl)-5-(pyridine-4-yl)-1,3,4-oxadiazoles (10-16). The newly synthesized compounds 10-16 were confirmed by elemental (C, H, N) and spectral (IR, ${ }^{1} \mathrm{H}$ NMR and mass) analysis. Compounds 10-16 have been tested for their antibacterial activity using ampicillin as a reference compound.
\end{abstract}

Keywords: Pyridine, Oxadiazole, Antibacterial activity

\section{Introduction}

Heterocyclic system containing pyridine ring, constitute an important class of potentially bioactive compounds. The earlier workers reported that, pyridine derivatives are associated with a wide spectrum of biological activities viz antimicrobial ${ }^{1-2}$, anti-inflammatory ${ }^{3}$, antibacterial $^{4}$, anti-parkinsonian ${ }^{5}$, anticonvulsant ${ }^{6}$, analgesic ${ }^{7}$ etc. Similarly oxadiazole have shown a wide range of applications in drug development against convulsant ${ }^{8}$, inflammatory ${ }^{9}$, bacterial $^{10-11}$ and microbial ${ }^{12-13}$ etc. It is therefore thought worthwhile to synthesize some pyridine derivatives contain oxadiazole moiety with the hope to possess better antibacterial activity.

\section{Experimental}

The melting points of compounds were determined in open capillaries with the help of thermionic melting point apparatus and were uncorrected. The homogeneity of newly synthesized compounds was routinely checked by thin layer chromatography (TLC) Elemental analysis (C, H, N) of the synthesized compounds were determined by PerkinElmer 2400 elemental analyzer, and results were found within the $\pm 0.4 \%$ of theoretical values. 
The IR spectra were recorded on a Beckman Acculab-10 Spectrometer $\left(v_{\max }\right.$ in $\left.\mathrm{cm}^{-1}\right)$ and the ${ }^{1} \mathrm{H}$ NMR spectra were recorded by Brucker DPX-300MHz using $\mathrm{CDCl}_{3}$ as solvent. Mass spectra were determined on VG-70-S instrument. The synthesis of the target compounds was accomplished according to the reaction sequence illustrated in Scheme 1.

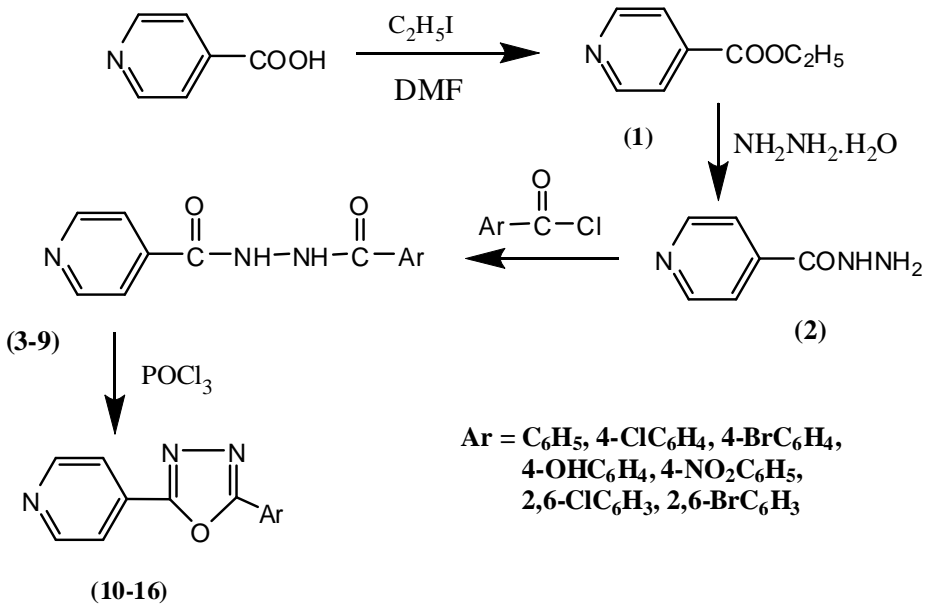

Scheme 1

Synthesis of ethyl-4-pyridinoate (1)

To a solution of pyridine-4-carboxylic acid (0.15 mol), dry DMF and ethyl iodide (0.15 mol) was added drop wise in $500 \mathrm{~mL}$ round bottom flask. The reaction mixture was stirred for $2-3 \mathrm{~h}$ at $20-25{ }^{0} \mathrm{C}$, reaction monitored by technique up to completion. After the reaction completed, ice water was added and stirred for $30 \mathrm{~min}$. The precipitate was collected by filtration technique, washed with water and recrystallized from ethanol to yield compound $\mathbf{1}$.

\section{Synthesis of pyridine-4-yl-carbonyl hydrazide (2)}

Dissolved the ethyl-4-pyridinoate $(0.1 \mathrm{~mol})$ in $30 \mathrm{~mL}$ of methanol and hydrazine hydrate (0.1 mol) was added drop wise to mixture with stirring. The resulting mixture was allowed to reflux for $8 \mathrm{~h}$. Excess of methanol was distilled out and the content was allowed to cool. The crystal formed was filtered, washed thoroughly with water, dried and recrystallized from methanol to afford compound 2.

General procedure for the preparation of $N$-substituted benzoyl pyridin-4-yl-carbonyl hydrazide (3-9)

A mixture of compound 2 ( $0.1 \mathrm{~mol})$ in dry ether, substituted benzoyl chloride $(0.2 \mathrm{~mol})$ were added with stirring for $7 \mathrm{~h}$. The reaction mixtures were refluxed for $6 \mathrm{~h}$ on water bath. The solvent was distilled off and the reaction mixtures were poured on to crushed ice. The solids thus obtained were filtered and re-crystallized from ethanol to yield compounds 3-9.

General procedure for the preparation of 2-(substituted phenyl)-5-(pyridine-4-yl)1,3,4-oxadiazoles (10-16)

Compounds 3-9 (0.1 mol) reacted with phosphorous oxychloride $(30 \mathrm{~mL})$ and refluxed gently for $30 \mathrm{~min}$ and cooled followed by careful addition of water $(90 \mathrm{~mL})$. The separated solid was filtered and suspended in water and basified with aqueous potassium hydroxide followed by filtration, drying and crystallization from ethanol to yield compounds 10-16. 


\section{Physical, elemental and spectral data of compounds 10-16}

2-Phenyl-5-(pyridine-4-yl)-1,3,4-oxadiazole (10)

Yield 71\% (ethanol); m.p. $110{ }^{\circ} \mathrm{C}$. IR (KBr max in $\mathrm{cm}^{-1}$ ): 1235 (C-O-C), 1284 (N-N), 1572 $(\mathrm{C}=\mathrm{N}), 1610$ (C-C of aromatic ring); ${ }^{1} \mathrm{H}$ NMR $\left(\mathrm{CDCl}_{3}+\mathrm{DMSO}_{6}\right) \delta$ in ppm: 7.45-8.46 (m, $9 \mathrm{H}, \mathrm{Ar}-\mathrm{H}$ ); Anal. Calcd. for $\mathrm{C}_{13} \mathrm{H}_{9} \mathrm{~N}_{3} \mathrm{O}$ : C, 69.95; H, 4.06; N, 18.82; Found: C, 69.93; H, 4.04; N, 18.85\%; MS: [M] $]^{+}$at $m / z 223.23$.

\section{2-(4-Chlorophenyl)-5-(pyridine-4-yl)-1,3,4-oxadiazole (11)}

Yield 66\% (methanol); m.p. $186{ }^{0} \mathrm{C}$. IR (KBr max in $\mathrm{cm}^{-1}$ ): 763 (C-Cl), 1238 (C-O-C), 1282 $(\mathrm{N}-\mathrm{N}), 1574(\mathrm{C}=\mathrm{N}), 1612$ (C-C of aromatic ring); ${ }^{1} \mathrm{H}$ NMR $\left(\mathrm{CDCl}_{3}+\mathrm{DMSO}_{6}\right) \delta$ in ppm: 7.51-8.50 (m, 8H, Ar-H); Anal. Calcd. for $\mathrm{C}_{13} \mathrm{H}_{8} \mathrm{ClN}_{3} \mathrm{O}$ : C, 60.60; H, 3.13; N, 16.31; Found: C, 60.62; H, 3.14; N, 16.33\% ; MS: [M] ${ }^{+}$at $m / z 257.68$.

\section{2-(4-Bromophenyl)-5-(pyridine-4-yl)-1,3,4-oxadiazole (12)}

Yield 69\% (ethanol); m.p. $218{ }^{0} \mathrm{C}$. IR (KBr max in $\mathrm{cm}^{-1}$ ): 613 (C-Br), 1234 (C-O-C), 1287 $(\mathrm{N}-\mathrm{N}), 1574(\mathrm{C}=\mathrm{N}), 1613\left(\mathrm{C}-\mathrm{C}\right.$ of aromatic ring); ${ }^{1} \mathrm{H}$ NMR $\left(\mathrm{CDCl}_{3}+\mathrm{DMSO}_{6}\right) \delta$ in ppm: 7.50-8.52 (m, 8H, Ar-H); Anal. Calcd. for $\mathrm{C}_{13} \mathrm{H}_{8} \mathrm{BrN}_{3} \mathrm{O}$ : C, 51.68; H, 2.67; N, 13.91; Found: C, 51.65; H, 2.70; N, 13.90\%; MS: [M] ${ }^{+}$at $\mathrm{m} / \mathrm{z} 302.13$.

\section{2-(4-Hydroxyphenyl)-5-(pyridine-4-yl)-1,3,4-oxadiazole (13)}

Yield 65\% (acetone); m.p. $981{ }^{0} \mathrm{C}$. IR ( $\mathrm{KBr} \max$ in $\mathrm{cm}^{-1}$ ): 1235 (C-O-C), 1284 (N-N), 1570 $(\mathrm{C}=\mathrm{N}), 1611$ (C-C of aromatic ring), $3452(\mathrm{OH}) ;{ }^{1} \mathrm{H} \mathrm{NMR}\left(\mathrm{CDCl}_{3}+\mathrm{DMSO}_{6}\right) \delta$ in ppm: 7.538.54 (m, 8H, Ar-H), 11.82 (s, $1 \mathrm{H}, \mathrm{OH}$ exchangeable with $\mathrm{D}_{2} \mathrm{O}$ ); ; Anal. Calcd. for $\mathrm{C}_{13} \mathrm{H}_{9} \mathrm{~N}_{3} \mathrm{O}_{2}$ : C, 65.27; H, 3.79; N, 17.56; Found: C, 65.29; H, 3.76; N, 17.57\%; MS: [M] ${ }^{+}$at $\mathrm{m} / \mathrm{z} 239.23$.

\section{2-(4-Nitrophenyl)-5-(pyridine-4-yl)-1,3,4-oxadiazole (14)}

Yield 62\% (methanol); m.p. $210{ }^{\circ} \mathrm{C}$. IR ( $\mathrm{KBr} \max$ in $\mathrm{cm}^{-1}$ ): 1237 (C-O-C), $1281(\mathrm{~N}-\mathrm{N})$, $1573(\mathrm{C}=\mathrm{N}), 1610$ (C-C of aromatic ring); ${ }^{1} \mathrm{H}$ NMR $\left(\mathrm{CDCl}_{3}+\mathrm{DMSO}_{6}\right) \delta$ in ppm: 7.508.55 (m, 8H, Ar-H); Anal. Calcd. for $\mathrm{C}_{13} \mathrm{H}_{8} \mathrm{~N}_{4} \mathrm{O}_{3}$ : C, 58.21; H, 3.01; N, 20.89; Found: C, 58.24; H, 3.03; N, 20.87\%; MS: [M] ${ }^{+}$at $m / z 268.23$.

\section{2-(2,6-dichlorophenyl)-5-(pyridine-4-yl)-1,3,4-oxadiazole (15)}

Yield 57\% (ethanol); m.p. $228{ }^{0} \mathrm{C}$. IR (KBr max in $\mathrm{cm}^{-1}$ ): 765 (C-Cl), 1232 (C-O-C), 1282 $(\mathrm{N}-\mathrm{N}), 1570(\mathrm{C}=\mathrm{N}), 1613$ (C-C of aromatic ring); ${ }^{1} \mathrm{H}$ NMR $\left(\mathrm{CDCl}_{3}+\mathrm{DMSO}_{6}\right) \delta$ in ppm: 7.51-8.52 (m, 7H, Ar-H); Anal. Calcd. for $\mathrm{C}_{13} \mathrm{H}_{7} \mathrm{Cl}_{2} \mathrm{~N}_{3} \mathrm{O}$ : C, 53.45; H, 2.42; N, 14.38; Found: C, 53.47; H, 2.41; N, 14.35\%; MS: [M] $]^{+}$at $\mathrm{m} / \mathrm{z} 292.12$.

2-(2,6-dibromophenyl)-5-(pyridine-4-yl)-1,3,4-oxadiazole (16)

Yield 54\% (acetone); m.p. $239{ }^{0} \mathrm{C}$. IR (KBr max in $\left.\mathrm{cm}^{-1}\right)$ : 612 (C-Br), 1245 (C-O-C), 1286 $(\mathrm{N}-\mathrm{N}), 1573(\mathrm{C}=\mathrm{N}), 1610\left(\mathrm{C}-\mathrm{C}\right.$ of aromatic ring); ${ }^{1} \mathrm{H}$ NMR $\left(\mathrm{CDCl}_{3}+\mathrm{DMSO}_{6}\right) \delta$ in ppm: 7.53-8.50 (m, 7H, Ar-H); Anal. Calcd. for $\mathrm{C}_{13} \mathrm{H}_{7} \mathrm{Br}_{2} \mathrm{~N}_{3} \mathrm{O}$ : C, 40.98; H, 1.85; N, 11.03; Found: C, 40.96; H, 1.87; N, 11.05\%; MS: [M] $]^{+}$at $\mathrm{m} / \mathrm{z} 381.02$.

\section{Results and Discussion}

The compounds 10-16 were screened for their antibacterial activity against the bacteria $S$. aureus, E. coli, $P$. vulgaris and $K$. pneumonia following the cup plate method ${ }^{14}$ at $250 \mu \mathrm{g} / \mathrm{mL}$ concentrations. The results are given in Table 1 . The compounds 11 and 14 exhibiting good activity against all different bacteria. Among the compounds 10-16, compounds 15 and 16 exhibited potent antibacterial activity than standard drug ampicillin against S. aureus, E. coli, P. vulgaris and K. pneumonia. All the remaining compounds exhibited moderate activity against all the organism used for screening. 
Table 1. Antibacterial activity of the compounds 10-16

\begin{tabular}{cccccc}
\hline \multirow{2}{*}{ Compd.No. } & \multirow{2}{*}{$\mathrm{Ar}$} & \multicolumn{4}{c}{ Bacterial growth inhibition(diameter in mm) } \\
\cline { 3 - 6 } & & S.aureus & E. coli & P. vulgaris & K. pneumoniae \\
\hline $\mathbf{1 0}$ & $\mathrm{C}_{6} \mathrm{H}_{5}$ & 16 & 13 & 14 & 10 \\
$\mathbf{1 1}$ & $4-\mathrm{ClC}_{6} \mathrm{H}_{4}$ & 19 & 16 & 17 & 13 \\
$\mathbf{1 2}$ & $4-\mathrm{BrC}_{6} \mathrm{H}_{4}$ & 17 & 13 & 11 & 10 \\
$\mathbf{1 3}$ & $4-\mathrm{OHC}_{6} \mathrm{H}_{4}$ & 15 & 14 & 13 & 12 \\
$\mathbf{1 4}$ & $4-\mathrm{NO}_{2} \mathrm{C}_{6} \mathrm{H}_{4}$ & 20 & 17 & 18 & 14 \\
$\mathbf{1 5}$ & $2,6-\mathrm{ClC}_{6} \mathrm{H}_{3}$ & 25 & 21 & 23 & 17 \\
$\mathbf{1 6}$ & $2,6 \mathrm{BrC}_{6} \mathrm{H}_{3}$ & 23 & 20 & 19 & 15 \\
Ampicillin & & 20 & 18 & 18 & 14 \\
\hline
\end{tabular}

\section{Conclusion}

The successful synthesis of series of heterocyclic compounds and evaluation of the antibacterial activity of oxadiazole derivatives of pyridine were reported. 2,6-Dichlorogroup in oxadiazole ring showed more efficiency due to presence of more electronegative atom.

\section{Acknowledgement}

We are thankful to SAIF Punjab University, Chandigarh India for spectral and analytical analysis of newly synthesized compounds. We are also thankful to Department of Microbiology LLRM Medical College Meerut UP, India for their antibacterial activity.

\section{References}

1. Javed A, Bhatia M S, Shinde M and Singh V, Indian J Pharm Biol Res., 2013, 1(3), 1-7.

2. $\quad$ Patel N B, Agraval S N and Shaikh F M, Med Chem Res., 2011, 20, 1033-1041; DOI:10.1007/s00044-010-9440-0

3. Muthal N, Ahirwar J, Ahriwar D, Masih P, Mahmdapure T and Sivakumar T, Int J Pharm Tech Res., 2010, 2(4), 2450-2455.

4. Foks K G, Kedzia A, Kwapisz E, Olczak A and Glowka M L, J Heterocycl Chem., 2013, 50(3), 544-550; DOI:10.1002/jhet.1518

5. Al-Omar M A, Amr Ael G and Al-Salahi R A, Arch Pharm (Weinheim), 2010, 343(11-12), 648-656; DOI:10.1002/ardp.201000088

6. Pattan S R, Dighe N S, Musmade D S, Tambe S K, Kale S H, Craware V M and Prerna A C, J Chem Pharm Res., 2010, 2(1), 246-252.

7. Chaubey A K and Pandeya S N, International Journal of Research in Ayurveda \& Pharmacy, 2011, 2(6), 1763-1767.

8. Singh P, Sharma P K, Sharma J K, Upadhyay A and Kumar N, Org Med Chem Lett., 2012, 2(8), 1-10.

9. $\quad$ Singh A K, Lohani M and Parthsarthy R, Iranian J Pharma Res., 2013, 12(2), 319-323.

10. Raval J P, Akhaja T K N, Jaspara D M, Myangar K N and Patel N H, J Saudi Chem Soc., 2014, 18(2), 101-106; DOI:10.1016/j.jscs.2011.05.019

11. Deshmukh R, Jha A K, Thakur A S and Dewangan D, Int J Res Pharm Biomed Sci., 2011, 2(1), 215-219.

12. Islam M, Siddiqui A A, Rajesh R, Bakht A and Goyal S, Acta Pol Pharm-Drug Res., 2008, 65(4), 441-447.

13. Kumar R, Yar M S, Rai A K and Chaturvedi S, Der Pharmacia Lett., 2013, 5(1), 366-370.

14. Greenwood D, Slack R C B and Peutherer J F, In Medical Microbiology, $14^{\text {th }}$ Edition, London, 1992, 1. 